\title{
Commentar
}

zur

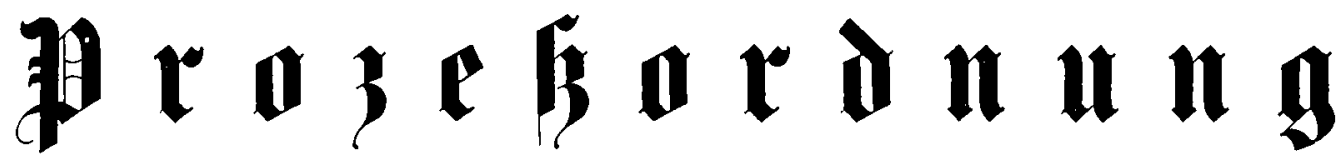

in

\section{biirgerliden Redtaftreitigfeiten}

für ถุะ

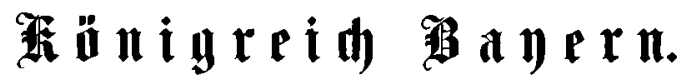

Bon

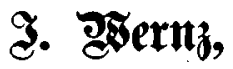

Rath am fgl. Dberappellationsigeriate.

Grfte abtheilung,

enthaltend $8 \mathfrak{B d}$ I und II.

苗 iindjen 1871.

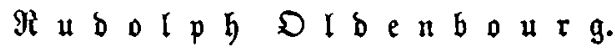


